\title{
The Functions of the Organizational Culture the Hospital Wahidins Sudirohusodos as a Public Organization
}

\author{
Wiwin Winangsih \\ H. Makmur \\ Suradi Tahmir

\begin{abstract}
Department of Public Administration, Universitas Negeri Makassar, Jin. Bonto Langkasa Kampus Gunung Sari Baru, Makassar, South Sulawesi, Indonesia Email: wiwinwinangsih75@yahoo.com,makmurstia@gmail.com, radita_unm@yahoo.com
\end{abstract}

\author{
Doi:10.5901/mjss.2017.v8n2p171
}

\begin{abstract}
The purpose of this research is to analyze the functions of organizational culture values the General Hospital Center Wahidin Sudirohusodo Makassar. This research is qualitative research approach of case studies. The data source is the primary data and secondary data. Primary data obtained through observation against the social situation and structured interview to informant. Secondary data obtained through documentation. Technique of data analysis is done through stages; data collection, data presentation, data reduction, and conclusion. This research is the indicator functions of organizational culture (motivation, social cohesion, and sense-making and control mechanism). The results of this study indicate that the values of culture organizations General Hospital Center Wahidin Sudirohusodo Makassar serves as a motivation source, social cohesion source, and sense-making and control mechanism. It can be demonstrated that: 1) the value of collaboration (teamwork) serve as a motivation source, by conducting all activities in a teamwork, evoking motivation on medical and non-medical personnel of the hospital; 2) value empathy serves of social cohesion source and these values also inspired leadership of hospitals to innovate and create a policy of people oriented, and 3) professional values serve as sense-making and control mechanism or transformed human resources ' attitude and behavior patterns, this value also form an aggressive working attitude and competitive on medical and non-medical personnel of the hospital. Organization culture values the General Hospital Center Wahidin Sudirohusodo Makassar has become a shared basic assumptions and guidelines for medical and non-medical personnel in providing medical services to the community.
\end{abstract}

Keywords: the function of organizational culture

\section{Introduction}

Public administration is a process of cooperation and coordination is being done by a few people to provide service to the community, public administration is public policy (Pfiffner and Robert V. Presthus (Safiie, 1999, p. 24). In addition, Nigro and Lloyd (Safiie, 1999, p.24) explains that the public administration is the process of cooperation of some people for the public interest. Public organizations still dominate nearly all aspects of people's lives in developing countries. Empirical facts illustrate that public organizations still live three functions, i.e. functions; Management (setting), distribution, and public service.

A public organization is a tool of the Government in providing services to the community. In addition, a public organization is obliged to steer, facilitate, guide and create an atmosphere that support the activities of the community. Therefore, the public should have the Organization and implement the organizational culture of the public properly. Organizational culture at public organizations can be functioned as social identity, the social stability, guidelines, as well as attitudes and behavior patterns of common resource human. Organizational culture can also be used as a unifying (social cohesion), a source of inspiration, a source of Activator (motivation), the increase in the value added, the formal successor, and mechanisms of adaptation to changes (Robbins, 2002).

The Central General Hospital Wahidin Sudirohusodo Makassar is Implementing Technical Unit (UPT) Ministry of health, with the Agency's financial management patterns of public service. In 2014, the Central General Hospital Wahidin Sudirohusodo Makassar was designated as international standard hospital after gaining Accreditation $\mathrm{JCl}$ Accreditation plenary and KARS. On the 17th of October 2014, the Ministry of health of the Republic of Indonesia issued a decision letter No. HK. 02.02/MenKes/390/2014 regarding the determination of the status of the General Hospital Center Wahidin 
Sudirohusodo Makassar, became a national hospital reference. (Wahidin Sudirohusodo Hospital, 2016).

Based on the above background, the purpose of this study was to describe the functions of the cultural values of the Organization at the General Hospital Center Wahidin Sudirohusodo Makassar. The dimension of the functions of organizational culture is a function as Motivation source, social cohesion, and transformed the people's attitude and behavior patterns.

Robbins (2002) and Wibowo (2010) explains that the organizational culture of the public can be enabled as social identity, social stability, guidance, sense-making and control mechanism on the human resources of the organization. In addition, the organizational culture can be used as social cohesion, a inspiration sources, a motivation sources, the valued added improvement, change of formalization, and adaptation mechanism of change, as well as attitudes and behavior patterns that formed (transformed people's attitude and behavior patterns).

As the Government hospitals (public organization), the General Hospital Center Wahidin Sudirohusodo Makassar has had the values of the culture of the Organization in providing medical services. Organization culture values is innovation, professional, empathetic, and cooperation. As the standard of the Government hospital, a General Hospital International Center Wahidin Sudirohusodo Makassar must perform its functions well with characters guided by the values of the culture of the organization.

Concept of research can be views on the conceptual framework of the scheme below:

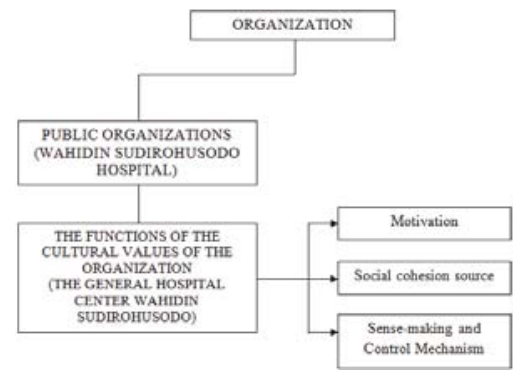

Figure 1: Conceptual Framework

\section{Research Methods}

\subsection{Informants}

There are 66 informants involved in this research (20 men, 16 women with age between 28-50 years). There are 2 doctors, 4 nurses, 8 patients. 5 wife and husband of 7 families of patients. 4 workers, 3 security officers and 2 Park cleaner who had worked at the hospital for 2 up to 8 years. Both doctors have worked at the hospital for 20 years, with the age of around 55 years (men's doctor) and 50 years (female doctor). The nurse had been working for 4 years, with an average age of 30 years. Shine garden, average age 30 years old and have been working for 3 years. While the Security Officer (28 year old) and have been working for 2 years. Patients were interviewed between the ages of 20-60 years. This research informants is divided in two sources, namely the internal informer (medical and non-medical) and external informants (patients and families). Internal informants obtained by purposive sampling technique ' ' temporary external informants obtained through "snowball sampling technique".

This qualitative research approach applied in the semi-structured interview for received data. This research data collection technique is a structured interview.

\subsection{Procedure}

The analysis of this research was done through 4 stages, namely: 1) data collection, 2) data reduction, 3) display data, and 4) conclusion (synthesis). Individual interviews were conducted at the hospital for 90 minutes. The informant asked seven questions related to the cultural values of the Organization and its functions. The interview process was recorded and written in the form of transcription. Analysis is conducted to find deployment functions of the cultural values of the Organization at the hospital. Documentation is conducted to support proof of deployment functions of the cultural values of the Organization at the hospital. 


\section{Research Results}

The results of the interviews stated that organizational culture values the General Hospital Center Wahidin Sudirohusodo Makassar (Professional, innovation, empathy, and cooperation), has been enabled.

\subsection{The source of motivation}

The value of cooperation in culture organizations General Hospital Center Wahidin Sudirohusodo Makassar has been enabled to motivate the human resources of the hospital. According to Usman (2009), motivation is the psychological process that encourages someone to do something. Armstrong (1999, p. 58) explains that the motivation is divided in two dimensions, namely: a) extrinsic (something that is conducted to motivate someone), and b) intrinsic (encouragement from within one's self).

To motivate medical and non medical personnel of the hospital, its leader, formed a team collaboration (teamwork). General Hospital Center Wahidin Sudirohusodo Makassar has 3 levels of teamwork in serving the community. The teamwork among others is the leader of team work, team work skills, and a non structural team work. All activities done by teamwork. In teamwork, they may be sharing your opinions and suggestions.

"We are motivated to work with the teamwork, teamwork coordination convenes every before or after doing the activities. Coordination meetings are meant for sharing opinions and suggestions, and also reports what we've done. "(Object 1. Interviewed, March 9, 2016).

In addition, the hospital has a special team work in providing medical services in the hospitalization. Each room has an inpatient teamwork responsible care activities at all. Any teamwork consists of 6 people, namely medical staff; 1) doctor in charge. 2) Person in charge of maintenance. 3) Team doctor. 4) Leadership teamwork. 5) Nurses. 6) Dietician. In general the teamwork tasks, namely; 1) identify patient. 2) Communicating with patients effectively. 3) Control the drug patients. 4) Reduces the risk of infection (with hand washing). 5) Acting at the right place, the right procedure, perform the appropriate operation on the patient and 6) avoid the risk of the patient.

The responsibility of a physician is to diagnose and treat patients. Each patient was accompanied by a doctor expert. The head nurse is the leader on the inpatient room charge on all forms of treatment needed by the patient, for example, need food and medicine. The leadership team work to coordinate the activities of medical and assisted by a nurse and dietician. The nurse helps the doctor to check a patient's blood pressure and store medical records of patients. Teamwork on the inpatient room always coordinate before and after doing its job.

All the activities that have been described above, the authors conducted with great motivation. Each Member of the teamwork Seem very motivated in doing its job. They are no longer waiting for his command in carrying out its work. They are very familiar and exchanging advice and experience in each meeting coordination. Torang (2013) explained that ' coordination meeting aims to synchronize all activities and time of implementation activities, meetings coordination helps maximize the close teamwork performance and to improve the participation of teamwork in making planning early, in order to be accepted by the other members of the teamwork.

\subsection{Social Cohesion Source}

The value of empathy on culture organizations General Hospital Center Wahidin Sudirohusodo have also functioned as social cohesion. In realizing these functions, all forms of service at the hospital must be within the concept of "people oriented". Robbins (2002) explains that people oriented policy means that all organizations can give a good influence to society or on the human resources of the organization. Management medical and non medical services at General Hospital Center Wahidin Sudirohusodo applied in the concept of "people oriented". Every leadership teamwork respect and appreciate teamwork members. Similarly members of teamwork respect and appreciate every patient served.

The value of empathy as social cohesion source, has been in the guidelines as the primary value by all the medical and non-medical personnel of the hospital. Nasucha (2004, p.79) explained that the primary value that has been on the guidelines and the basic assumption become joint members of your organization can be said as a strong culture. When many members of the Organization guided by the primary value, then it is indicative of a strong commitment on that value. To implement the concept of people oriented, General Hospital Center Wahidin Sudirohusodo provides remuneration to all medical and non-medical personnel. In addition, the leadership of these hospitals also provide a reward to all medical and non-medical personnel that good performance. 
"The leadership of the reward to provide medical and non medical personnel whose performance is good and comes to work on time". (Object 2. Interviewed, March 9, 2016).

The value of empathy not only functioned as social cohesion among the medical and non-medical personnel in the General Hospital Center Wahidin Sudirohusodo, but also functioned as social cohesion to the patient and his family. In implementing the value of empathy as a source of social cohesion, head of the General Hospital Center Wahidin Sudirohusodo do innovation.

Innovation in public organizations according to Greenberg and Baron (1997) is the work of conducted by the Organization's resources to find or create new ideas in the workplace. Robbins (2002, p. 248) explained that innovation in the organization is the work of conducted by the Organization's resources to find something new. One of the innovations undertaken by the leadership of the General Hospital Center Wahidin Sudirohusodo is to provide a rest area for families of patients come from outside the city. Resting place of this sort are not found in other hospitals in Sulawesi.

"I feel so glad because it provides a place to stay overnight or have a rest in the evening" (the object 3. interviewed, March 9, 2016).

Resting place is not merely a place to wait, but also as a place to interact and communicate with the patient's family. In the room breaks, they discuss about the health condition of his illness. In addition, the site became a place of merging their families who had long not bump into each other.

"In place of the rest I can also discuss and relaxation with the family that has long been not bump into each other". (Object 4. interviewed March 9, 2016).

\subsection{Sense-making and Control Mechanism}

Professional values in organizational culture General Hospital Center Wahidin Sudirohusodo serves as a sense-making and control mechanism or transformed human resources ' attitude and behavior pattern. Deployment Professional value means that the leadership of at General Hospital Wahidin Sudirohusodo enable the value of combining professional attitude and behavior of medical and non-medical personnel as well as a mechanism of control on their activities. This is also the strategy of the command at General Hospital Wahidin Sudirohusodo in increasing aggressiveness and competitiveness of medical and non medical personnel in providing service to the community.

In addition, to improve professionalism, aggressiveness and competitiveness of medical and non-medical personnel, then any leadership teamwork at the General Hospital Center Wahidin Sudirohusodo supervises the activities of a member of his teamwork. The surveillance is intended to; 1 ) know the suitability of staff competencies with tasks given (the right man on the right place), 2) know the suitability of time by learning outcomes and outputs, 3) guarantees that the work according to the plan, 4) measuring outcomes and outputs, 5) analyzes the sustainability of development work with the monitoring work being done, and 6) minimize, avoid, or resolve handicap factors.

Because of the reward and controlling done by their respective leadership teamwork, resulting in all the medical and non-medical personnel in General Hospital Center Wahidin Sudirohusodo work with professional, aggressive competitive. By working professional, aggressive and competitif, all the medical and non-medical personnel in General Hospital Center Wahidin Sudirohusodo do its job well and detail (attention to detail). In addition, the General Hospital Center Wahidin Sudirohusodo already have standard operational procedures (SOP), document the care of patients (COP), and standard management administration.

Therefore, in carrying out its task, every medical and non medical personnel referring to standard operational procedures (SOP) and document care of patients (COP). This indicates that the General Hospital Center Wahidin Sudirohusodo have given undivided attention and detail to give the servant to the community. General Hospital Center Wahidin Sudirohusodo also has a Commission of ethics which oversees all staff as well as testing the wrong medical staff provides services to patients. The duties and functions of the ethics commission is to assure to all hospital staff to perform with professional and detail.

In addition, in order to keep all the tasks and functions are implemented well and detail, the General Hospital Center Wahidin Sudirohusodo provides a special place for waste destruction while maintaining the health of the environment. The hospital has two places where the destruction of waste, destruction of wet waste and dry waste. However, there is still one thing which has not been made by the leadership of the General Hospital Center Wahidin Sudirohusodo professionally and detail, i.e. parking area. 
"Parking is very limited at this hospital and cannot accommodate the large number of officers and the patient's family vehicle" (Object 5. interviewed, March 9, 2016)

In addition, to apply professional values, the hospital has established attitudes and patterns of behavior of its human resources with the work on the task in process approach than outcomes oriented. So that all patients are well catered for, any medical personnel on the General Hospital Center Wahidin Sudirohusodo have to prioritize in process oriented against all forms of medical service. As a public organization, the hospital prefer process oriented than on learning outcomes oriented (achieving maximum benefit).

The hospital policy in line with the opinion Torang (2013) in organization and management explaining that the organization management prefer the process to get the ' output ' and ' learning outcomes '. Utilizing a process approach to empower human resources and other resources to achieve the objectives of the Organization, as well as leadership processes play an important role to perform the duties of a staff with a good which is set formally to achieve the goals of the organization.

"All medical activities in hospitals is conducted in a process approach in serving the patients. We should refer to the standard operational procedures and document the care of patient in serving patients "(Object 6. Interviewed, March 9 , 2016).

What has the author describe above, it gives a message that the organization management in hospital must be distinguished from the organization management in business organization (company). In achieving the objectives of its organization, the company is more oriented to learning outcomes (benefits) than on process-oriented.

\section{Conclusion}

The values of the culture of the Organization at the General Hospital Center Wahidin Sudirohusodo serves as a motivation source, social cohesion source, and sense-making and control mechanism. It can be demonstrated that: 1) the value of collaboration (teamwork) serve as a motivation source, by conducting all activities in a teamwork, evoking motivation on medical and non-medical personnel of the hospital; 2) value empathy serves as a social cohesion source and these values also inspired leadership of hospitals to innovate and create a policy people oriented, and 3) professional values serve as a sense-making and control mechanism or transformed human resources' attitude and behavior patterns, this value also form an aggressive working attitude and competitive on medical and non-medical personnel of the hospital.

Organization culture values the General Hospital Center Wahidin Sudirohusodo Makassar has become a shared basic assumptions and guidelines for medical and non-medical personnel in providing medical services to the community.

\section{References}

Armstrong, Michael and Angela Baron. 1998. Performance Management. London: Institute of Personnel and Development. Greeberg, Jerald and Robert A. Baron. 1997. Behavior in Organization. New Jersey: Prentice-Hall International, Inc. Nasucha, C. Reformasi Administrasi Publik: Teori dan Paraktek. Jakarta: Grasindo.

Robbins, Stephen P. 2002. Perilaku Organisasi. Jakarta: Prenhallindo.

Schein, Edgar H. 1997. Organizational Culture and Leadership. San Francisco: Jossey-Bass Publisher.

Syafiie, I, at all. 1999. IImu Administrasi Publik. Jakarta: Rineka Cipta.

Torang, S. 2013. Organisasi dan Manajemen. Bandung. Alfa Beta Bandung.

Wibowo. 2010. Budaya Organisasi: Sebuah Kebutuhan Untuk Meningkatkan Kinerja Jangka Panjang Jakarta: PT. Rajawali Pers. 
ISSN 2039-2117 (online)

ISSN 2039-9340 (print)
Mediterranean Journal of Social Sciences MCSER Publishing, Rome-Italy
Vol 8 No 2

March 2017 